\title{
IMPROVEMENT OF THE METHODOLOGY OF DETERMINING THE RATIONAL DIAMETER OF BOREHOLES \\ FOR BLASTING OPERATIONS
}

\section{A. Frolov, I. Litvinchuk}

NTUU "Igor Sikorsky Kyiv Polytechnic Institute"

vul. Borschagivska, 115, Kiev, 03056, Ukraine. E-mail: frolov@geobud.kiev.ua

Purpose. The aim of the work is to establish the most rational diameter of the borehole charge of an explosive for specific mining and geological conditions of field development. Methodology. To achieve this goal, the presented studies used: a method of complex analysis - for analyzing and summarizing previous scientific studies on the selection and installation of the most rational diameters of borehole charges in open pits; analytical and graphoanalytical methods - to improve the method of determining the diameter of the borehole charge during drilling and blasting operations in quarries in mountain ranges with varying degrees of fracturing. Results. According to the results of the research performed, it was established that the diameter of the borehole charge is one of the most important parameters for controlling the degree of fragmentation, and its choice depends on the strength and fracture of the rocks. An improved method for determining the rational diameter of wells for drilling and blasting in quarries has been proposed. An expression is obtained that relates the cost indicators of drilling and blasting to the main technological parameters of drilling and blasting operations, including the diameter of the borehole charge. For the mining and geological conditions of the career, dependencies have been constructed between the diameter of the downhole explosive charge and the cost of drilling and blasting for various rocks with different degrees of fracturing. The established diameters of the borehole charge when performing drilling operations of the SBSh-250 packs for rocks of various categories of fracture. Originality. Based on the presented analytical dependence, graphical dependences of changes in the cost of drilling and blasting operations for different diameters of a single explosive charge are obtained. They make it possible to establish the most rational diameters of wells in a quarry under specified conditions, taking into account the cutting degree of fracturing of the rock mass. Practical value. The results of the research allow for the determined mining-geological and technological conditions for the development of mineral deposits to determine the rational volume of explosive wells on the basis of taking into account the technical and economic performance of the enterprise.

Key words: explosion, diameter, well, charge, rock, quarry.

\section{УДОСКОНАЛЕННЯ МЕТОДИКИ ВИЗНАЧЕННЯ РАЦІОНАЛЬНОГО ДІАМЕТРУ СВЕРДЛОВИН ДЛЯ БУРОПІДРИВНИХ РОБІТ}

\section{О. О. Фролов, І. Д. Литвинчук}

НТУУ «Київський політехнічний інститут імені Ігоря Сікорського» вул. Борщагівська, 115, м. Київ, 03156, Україна. E-mail: frolov@geobud.kiev.ua Представлено дослідження щодо встановлення найбільш раціонального діаметра свердловинного заряду вибухової речовини для конкретних гірничо-

Сучасні ресурсоенергозберігаючі технології гірничого виробництва. Випуск 1/2019(23). 
геологічних умов відпрацювання родовища. Для розв'язання науково-дослідних задач використано комплексний метод досліджень, який складається з аналізу та узагальнення попередніх наукових досліджень щодо вибору та встановлення найбільш раціональних діаметрів свердловинних зарядів на кар'єрах та аналітичного удосконалення методики визначення діаметра свердловинного заряду при проведенні буропідривних робіт на кар'єрах в гірських масивах з різним ступенем тріщинуватості. За результатами виконаних досліджень встановлено, що діаметр свердловинного заряду є одним з найбільш важливих параметрів регулювання ступеня дроблення, а його вибір залежить від міцності та тріщинуватості порід. Запропоновано удосконалену методику визначення раціонального діаметру свердловин для буропідривних робіт на кар'єрах. Отримано вираз, який пов'язує вартісні показники буріння і підривання з основними технологічними показниками буропідривних робіт, в тому числі з діаметром свердловинного заряду. Для гірничо-геологічних умов залізорудного кар'єру побудовано залежності між діаметром свердловинного заряду вибухової речовини та вартістю буропідривних робіт для різних гірських порід з різним ступенем тріщинуватості. Встановлено раціональні діаметри свердловинного заряду при виконанні бурових робіт станками СБШ-250 для порід різної категорії тріщинуватості

Ключові слова: вибух, діаметр, свердловина, заряд, порода, кар'єр.

PROBLEM STATEMENT. Effective management of the process of explosive destruction of rocky mountain ranges is one of the most important scientific and technical tasks of mining. Its solution provides a reduction in the cost of both drilling and blasting operations (DBO) in a quarry in particular, and for mining in general.

The practical experience of carrying out DBO in quarries shows that obtaining the required quality of exploding crushing of rocky rocks only at the expense of increasing the specific consumption of explosives is not always effective. Therefore, there is a need to develop and improve other methods of managing explosive destruction, which will allow obtaining the required quality of destruction of mountain ranges without increasing the cost of blasting operations [1-5]. In connection with this improvement methodology for determining the rational diameter of blast holes in the quarries is an actual scientific and technical problem, the more so that the diameter of the wellbore determines the main parameters of the drilling and blasting operations.

The authors of [6] note that for smaller charge diameters, kill the charge lines deep into the array, the relative volume of the re-breeding rock around the charge decreases, and energy is distributed through the array with less losses. However, in some enterprises, while reducing the charge diameter from 200 to $100 \mathrm{~mm}$, there was no significant reduction in the cost of DBO. This is explained by the fact that the unit costs for disturbance of the array of drill-glasses of reduced diameter are much higher.

In [7], the effect of charge diameter on the efficiency of open-cast mining Kryvbas was investigated. It was recommended for iron ore quarries, which are characterized by the execution of works in strong and medium-hardened mountain ranges, to use wells with a diameter of $300 \mathrm{~mm}$, as the most effective in terms of technological and energy performance.

As noted by the authors of [8], a transition to the use of wells of optimal diameter may be a reserve for improving the efficiency of a complex of drilling and blasting

Сучасні ресурсоенергозберігаючі технології гірничого виробництва. Випуск 1/2019(23). 


\section{ТЕОРЕТИЧНІ Й ЕКСПЕРИМЕНТАЛЬНІ ДОСЛІДЖЕННЯ \\ ПРОЦЕСІВ РУЙНУВАННЯ ГІРСЬКИХ ПОРІД ВИБУХОМ}

operations in a quarry at great depths. For this, a mathematical model for determining the diameter of a well was developed, which is based on the general aspects of explosives. At the same time, some scientists note that the quality of grinding of the rock massif depends on the diameter of the charge, but it is not decisive from the number of parameters given [9].

Thus, according to the results of analysis of scientific research and publications, it has been established that the diameter of the borehole charge is one of the most important parameters for controlling the degree of fragmentation, and its choice essentially depends on the strength and fracturing of rocks. To date, it does not have an unambiguous reasonable theoretical solution for determining the rational diameter of the wellbore charge. Therefore, the aim of the work is to establish the most rational diameter of the downhole explosive charge for specific mining and geological conditions of the field development.

MATERIAL AND RESULTS. In order to obtain the rational values of borehole charge diameters for blasting operations in quarries, we use a technique based on the technical and economic assessment of the parameters of drilling and blasting [10,11].

In general, the total unit cost of drilling and blasting work is

$$
C_{D B O}=C_{D O}+C_{B O},
$$

where $C_{D O}$ - unit costs for drilling operations, UAH; $C_{B O}$ - unit costs for blasting, $\mathrm{UAH}$.

If we consider the costs of drilling and undermining, taking into account technological and technical-economic indicators, then the formula (1) takes the form

$$
C_{D B O}=\frac{4 q c_{d r}}{10^{-6} \pi d^{2} \Delta k_{u}}+c_{B O} q
$$

where $q$ - specific consumption of explosives, $\mathrm{kg} / \mathrm{m}^{3} ; c_{d r}$ - specific costs for drilling $1 \mathrm{~m}$ wells, $\mathrm{UAH} / \mathrm{m} ; d$-borehole diameter, $\mathrm{mm} ; \Delta$ - explosive loading density in charge, $\mathrm{kg} / \mathrm{m}^{3} ; k_{u}$ - the utilization of the volume of the well (on average take $k_{u}=0,65-0,75$ ); $c_{B O}-$ cost of $1 \mathrm{~kg}$ of explosives, taking into account the cost of charging, $\mathrm{UAH} / \mathrm{kg}$.

The specific consumption of explosives, taking into account the diameter of the downhole charge [11] and provided that the array is crushed into parts no larger than $500 \mathrm{~mm}$, can be represented as, $\mathrm{kg} / \mathrm{m}^{3}$

$$
q=0,13 \gamma \sqrt[4]{f}\left(0,6+3,3 \cdot 10^{-3} d_{o} d\right) \sqrt[5]{\left(\frac{500}{d_{m}}\right)^{2}},
$$

where $\gamma$ - rock density, $\mathrm{t} / \mathrm{m}^{3} ; f$ - strength factor on the Protodyakonov scale; $d_{o}-$ average size of natural separation in the array, $\mathrm{m} ; d$ - borehole charge diameter, $\mathrm{mm}$; $d_{m}$ - maximum allowable size of a piece of destroyed rock mass, $\mathrm{mm}$.

As we see, formula (3) takes into account the main factors that characterize the ability of a rock mass in explosive destruction, in particular, the strength and fracture of rocks.

Total costs for drilling and blasting (2) taking into account the specific consumption of explosives (3) will be

Сучасні ресурсоенергозберігаючі технології гірничого виробництва. Випуск 1/2019(23). 


$$
C_{D B O}=0,13 \gamma \sqrt[4]{f}\left(0,6+3,3 \cdot 10^{-3} d_{o} d\right) \sqrt[5]{\left(\frac{500}{d_{m}}\right)^{2}}\left(\frac{4 c_{d r}}{10^{-6} \pi d^{2} \Delta k_{u}}+c_{B O}\right) .
$$

As a result of mathematical transformations, we finally get

$$
\begin{gathered}
C_{D B O}=\gamma \sqrt[4]{f} \sqrt[5]{\left(\frac{500}{d_{m}}\right)^{2}} \cdot\left(7,8 \cdot 10^{-2} c_{B O}+4,29 \cdot 10^{-4} d_{o} d c_{B O}+\right. \\
\left.+\frac{0,31 \cdot 10^{6} c_{d r}}{\pi d^{2} \Delta k_{u}}+\frac{1,72 \cdot 10^{3} d_{o} c_{d r}}{\pi d \Delta k_{u}}\right) .
\end{gathered}
$$

If we substitute into the expression (5) the numerical values of the diameter of the charge, then it is possible, for mountain ranges of different strength and fracturing, provided that all indicators are established, to determine the total costs of drilling and blasting. The value of the minimum costs will correspond to the most effective diameter of the borehole charge.

For the mining and geological conditions of the iron ore quarry, studies were carried out to establish the relationship between the diameter of the downhole explosive charge and the cost of drilling and blasting for various rocks with varying degrees of fracturing. The following rocks predominate within the deposit: magnetite quartzites, silicate-magnetite quartzites (red), oxidized quartzites, low ore non-oxidized quartzites and substandard oxidation quartzites, rocks of shale horizons. Their main characteristics are given in table 1.

Table 1 - Physico-mechanical properties of iron ore quarry rocks

\begin{tabular}{|l|c|c|}
\hline \multicolumn{1}{|c|}{ Types of ores and rocks } & $\begin{array}{c}\text { Volume } \\
\text { weight, } \mathrm{t} / \mathrm{m}^{3}\end{array}$ & $\begin{array}{c}\text { The tensile strength of rocks in a } \\
\text { single compression dream, MPa }\end{array}$ \\
\hline Magnetite quartzite & 3,5 & $170-200$ \\
\hline Silicate magnetite quartzite & 3,25 & $180-250$ \\
\hline Oxidized quartzites & 3,3 & $40-150$ \\
\hline $\begin{array}{l}\text { Few ore non-oxidized quartzites and } \\
\text { substandard oxidation quartzites }\end{array}$ & 3,15 & $110-140$ \\
\hline Breeds of shale horizons & 3,15 & $110-120$ \\
\hline
\end{tabular}

The value of the average size of the natural separation in the array $d_{o}$ from the category of fracture are: for category I fracture $-d_{o}=0,1 \mathrm{~m}$; for category II $-d_{o}=0,3 \mathrm{~m}$; for category III $-d_{o}=0,75 \mathrm{~m}$; for category IV $-d_{o}=1,25 \mathrm{~m}$; for category V fracture $d_{o}=2,0 \mathrm{M}$.

The averaged technical and economic indicators of blasting operations of a career primoemo are as follows:

maximum allowable size of a piece of destroyed rock mass $-d_{m}=1200 \mathrm{~mm}$;

average well volume utilization $-k_{u}=0,7$;

average loading density of explosive Anemiks $70-\Delta=1250 \mathrm{~kg} / \mathrm{m}^{3}$;

cost of explosive Anemic $70-c_{B O}=16,1 \mathrm{UAN} / \mathrm{kg}$. 


\section{ТЕОРЕТИЧНІ Й ЕКСПЕРИМЕНТАЛЬНІ ДОСЛІДЖЕННЯ ПРОЦЕСІВ РУЙНУВАННЯ ГІРСЬКИХ ПОРІД ВИБУХОМ}

The calculations were performed under the condition of using drilling machines of the type SBSH-250. The average unit cost of drilling $1 \mathrm{~m}$ of wells is $c_{d r}=280 \mathrm{UAH} / \mathrm{m}$.

In fig. 1-5 shows the graphical dependences of the cost of DBO on the diameter of the well for different rocks with different categories of fracture, obtained in accordance with formula (5).

From the graphical dependences of Fig. 1, it can be seen that the category I of magnetite quartzite fracturing will be more appropriate for a diameter of $400 \mathrm{~mm}$, since the cost of DBO will be the minimum $C_{D B O}=9,01 \mathrm{UAH}$. For the second category of rocks, the most appropriate diameter is $350 \mathrm{~mm}$ with the minimum cost of DBO $C_{D B O}=12,14 \mathrm{UAH}$. Accordingly, for category III - d $=250 \mathrm{~mm}, C_{D B O}=18,21 \mathrm{UAH}$; for IV category of fracturing rocks $-d=250 \mathrm{~mm}, C_{D B O}=24,37 \mathrm{UAH}$; for the V category - $d=200 \mathrm{~mm}, C_{D B O}=33,33 \mathrm{UAH}$.

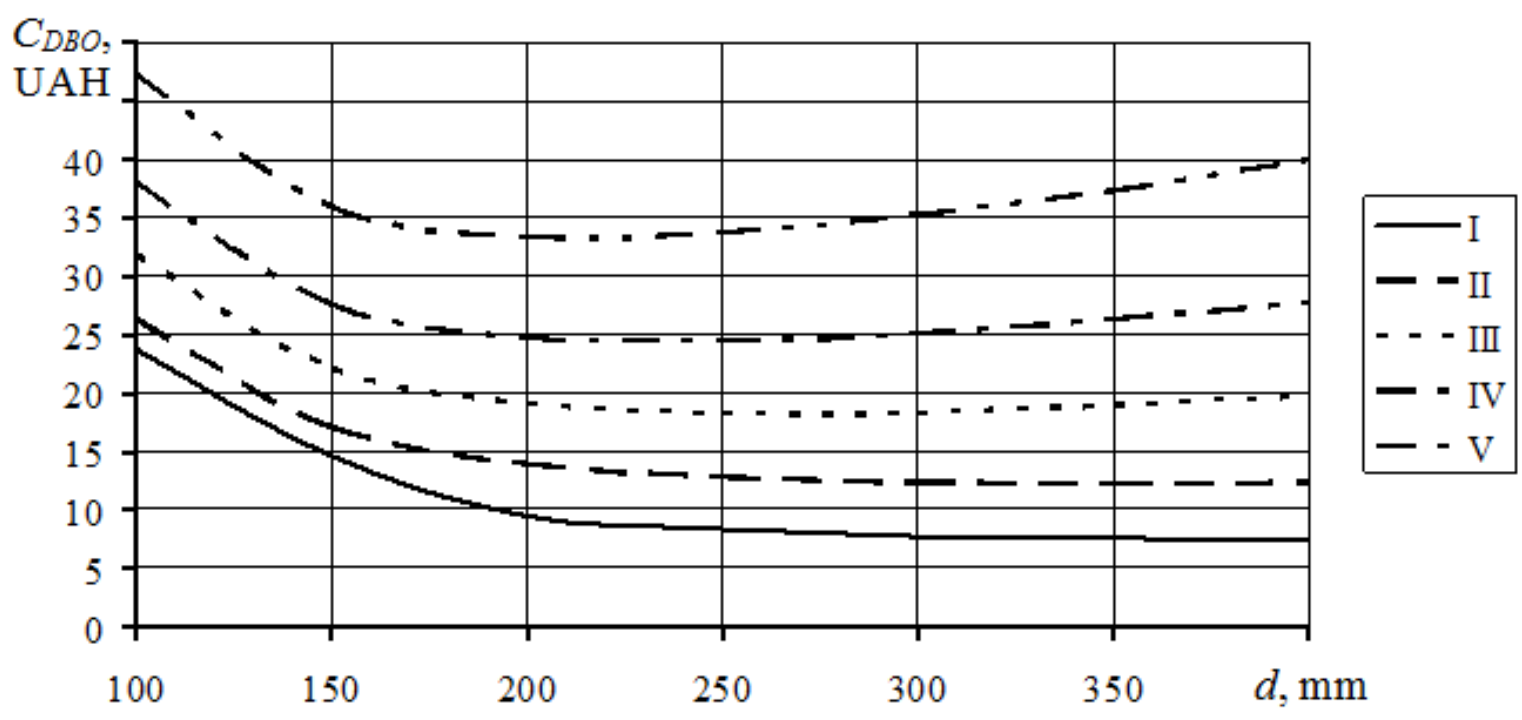

Figure 1 - The dependence of the specific cost of blasting on the diameter wells in magnetite quartzite with a different category of fracturing

Analysis of fig. 2 shows that for silicate-magnetite quartzites of rocks of the I category of fracturing, the most appropriate diameter will be $400 \mathrm{~mm}$, since the cost of DBO will be the minimum $C_{D B O}=8,90 \mathrm{UAH}$. For the second category, the most appropriate diameter is $350 \mathrm{~mm}$ at the lowest cost DBO $C_{D B O}=11,99 \mathrm{UAH}$. Accordingly, for category III $-d=250 \mathrm{~mm}, C_{D B O}=17,97 \mathrm{UAH}$; for IV category $-d=250 \mathrm{~mm}$, $C_{D B O}=24,06 \mathrm{UAH}$; for category $\mathrm{V}$ fracturing rocks $-d=200 \mathrm{~mm}, C_{D B O}=32,91 \mathrm{UAH}$.

For oxidized quartzites (Fig. 3) and the fracture category, the diameter of the borehole charge will be optimal $d=400 \mathrm{~mm}$, since the cost of DBO is minimal, namely $C_{D B O}=7,34 \mathrm{UAH}$. For the second category of rocks, the optimal diameter is $350 \mathrm{~mm}$ with the minimum cost of $\mathrm{DBO} C_{D B O}=9,88 \mathrm{UAH}$. Accordingly, for category III $-d=250 \mathrm{~mm}, C_{D B O}=14,82 \mathrm{UAH}$; for IV category $-d=250 \mathrm{~mm}, C_{D B O}=19,83 \mathrm{UAH}$; for V category $-d=200 \mathrm{~mm}, C_{D B O}=27,13 \mathrm{UAH}$. 
ТЕОРЕТИЧНІ Й ЕКСПЕРИМЕНТАЛЬНІ ДОСЛІДЖЕННЯ

ПРОЦЕСІВ РУЙНУВАННЯ ГІРСЬКИХ ПОРІД ВИБУХОМ

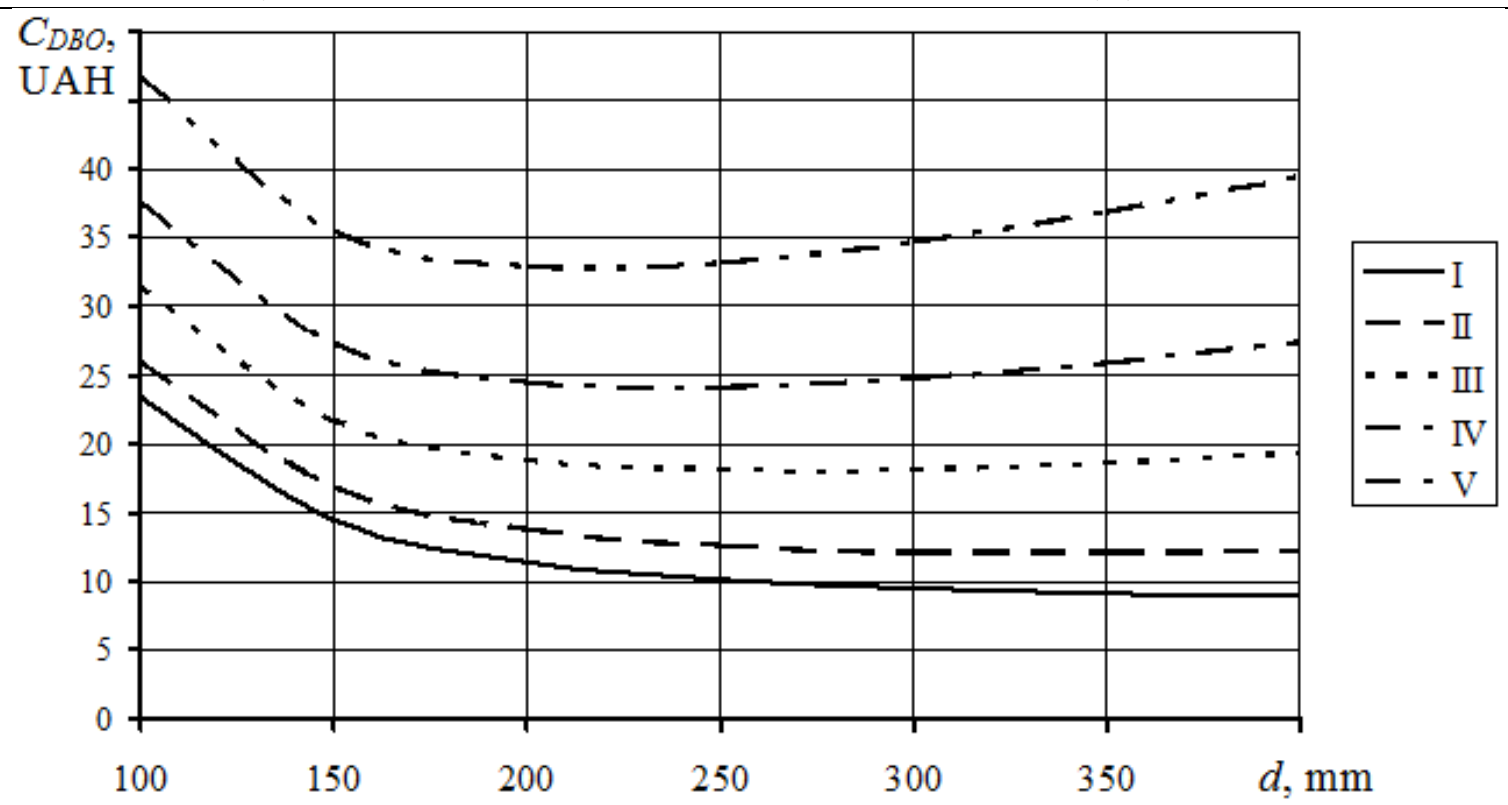

Figure 2 - Dependence of the specific cost of blasting on the diameter in silicate-magnetite quartzites (ore) at different fracture categories

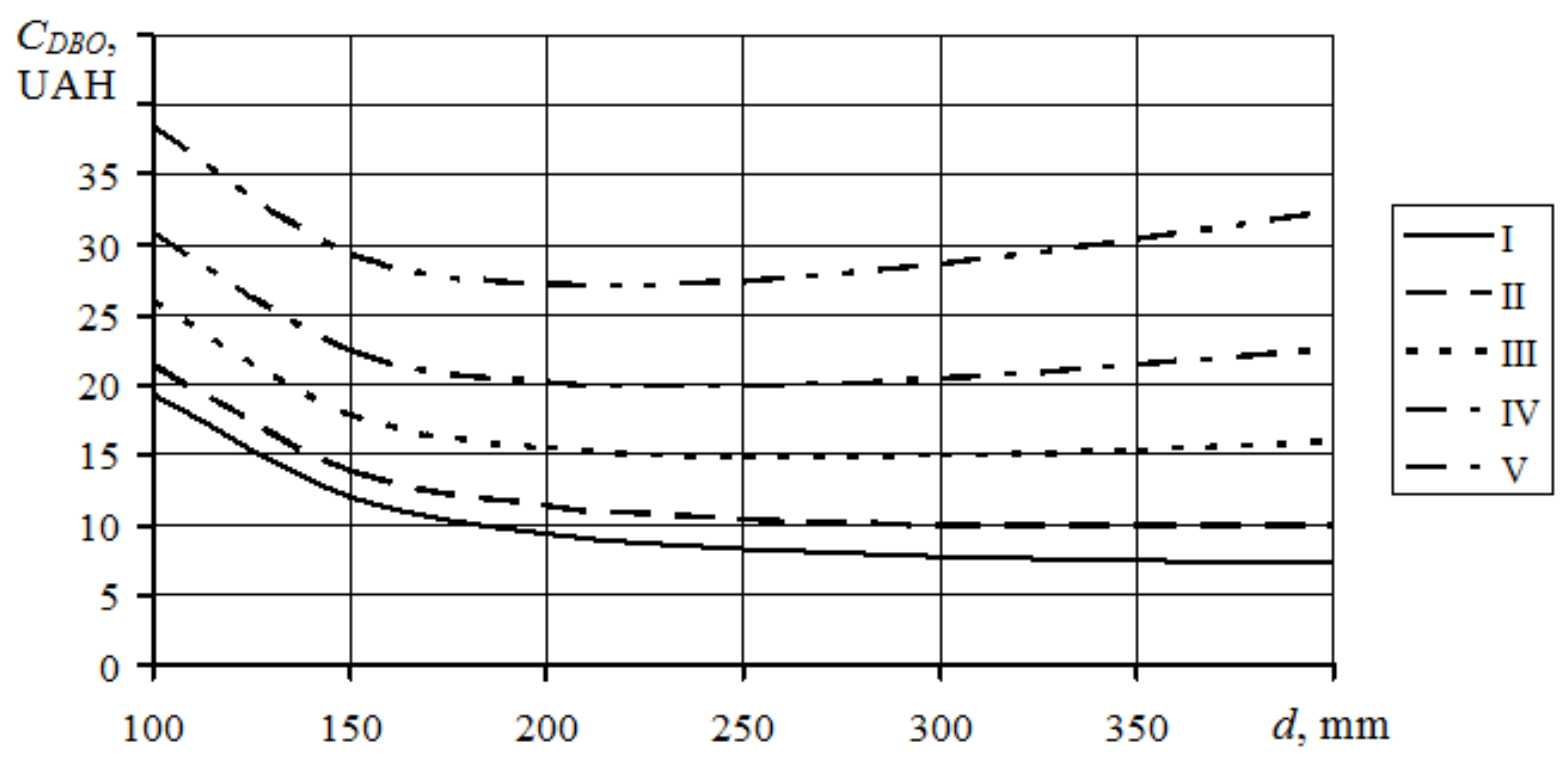

Figure 3 - The dependence of the cost of drilling and blasting operations on the diameter of the well in oxidized quartzites with different categories of fracture

For low-grade non-oxidized quartzites (Fig. 4) for Category I fracture, the minimum cost of $\mathrm{DBO}$ is $C_{D B O}=7,17 \mathrm{UAH}$, which corresponds to the optimal diameter $d=400 \mathrm{~mm}$. For the second category of fracture, the minimum cost of DBO is $C_{D B O}=9,66 \mathrm{UAH}$ at dimeters $d=350 \mathrm{~mm}$. Accordingly, for the III category of breeds the minimum value is $C_{D B O}=14,49 \mathrm{UAH}$, and the optimal diameter $d=250 \mathrm{~mm}$; for IV category - respectively $C_{D B O}=19,39 \mathrm{UAH}$ та $d=250 \mathrm{~mm}$; for category V fracture minimum value $C_{D B O}=26,52 \mathrm{UAH}$ will respond $d=200 \mathrm{~mm}$. 
ТЕОРЕТИЧНІ Й ЕКСПЕРИМЕНТАЛЬНІ ДОСЛІДЖЕННЯ

ПРОЦЕСІВ РУЙНУВАННЯ ГІРСЬКИХ ПОРІД ВИБУХОМ

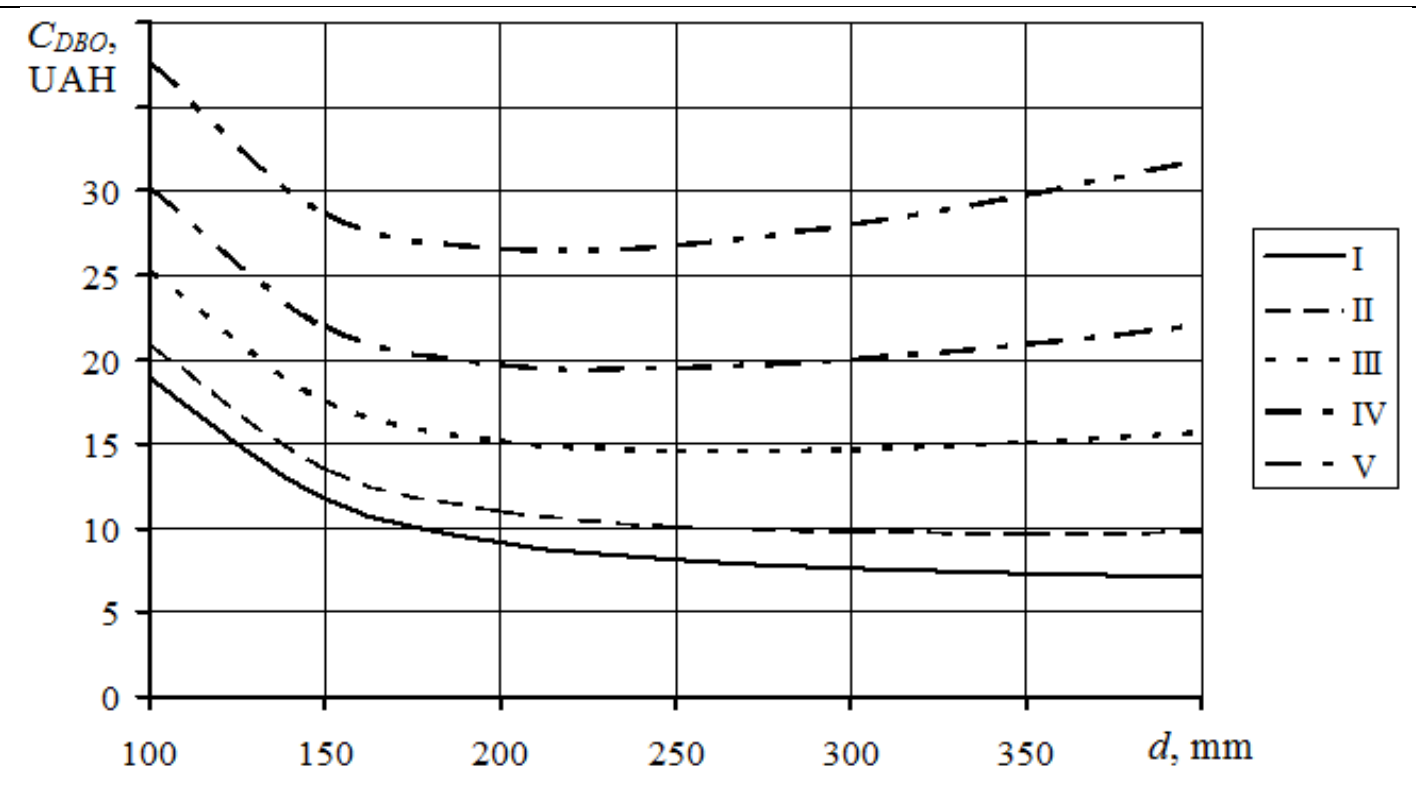

Figure 4 - The dependence of the cost of drilling operations on the diameter of the well in low ore non-oxidized quartzites with different categories of fracturing

In the rocks of the shale horizons for the first category of fracture, the diameter of $400 \mathrm{~mm}$ is most appropriate, since the minimum cost of DBO is equal to 7,33 $\mathrm{UAH}$ (Fig. 5). For the second fracture category, the optimal value of the diameter of the borehole charge $-d=350 \mathrm{~mm}$ for the minimum cost of DBO $C_{D B O}=9,87 \mathrm{UAH}$. Category III fractures will correspond to the minimum cost of DBO 14,81 UAH diameter value $250 \mathrm{~mm}$. IV category is characterized by the following values $-C_{D B O}=$ $19,82 \mathrm{UAH} ; d=250 \mathrm{~mm}$. In the $\mathrm{V}$ category of rock fracturing - the minimum cost of BPR is $27,11 \mathrm{UAH}$ for a charge diameter of $200 \mathrm{~mm}$.

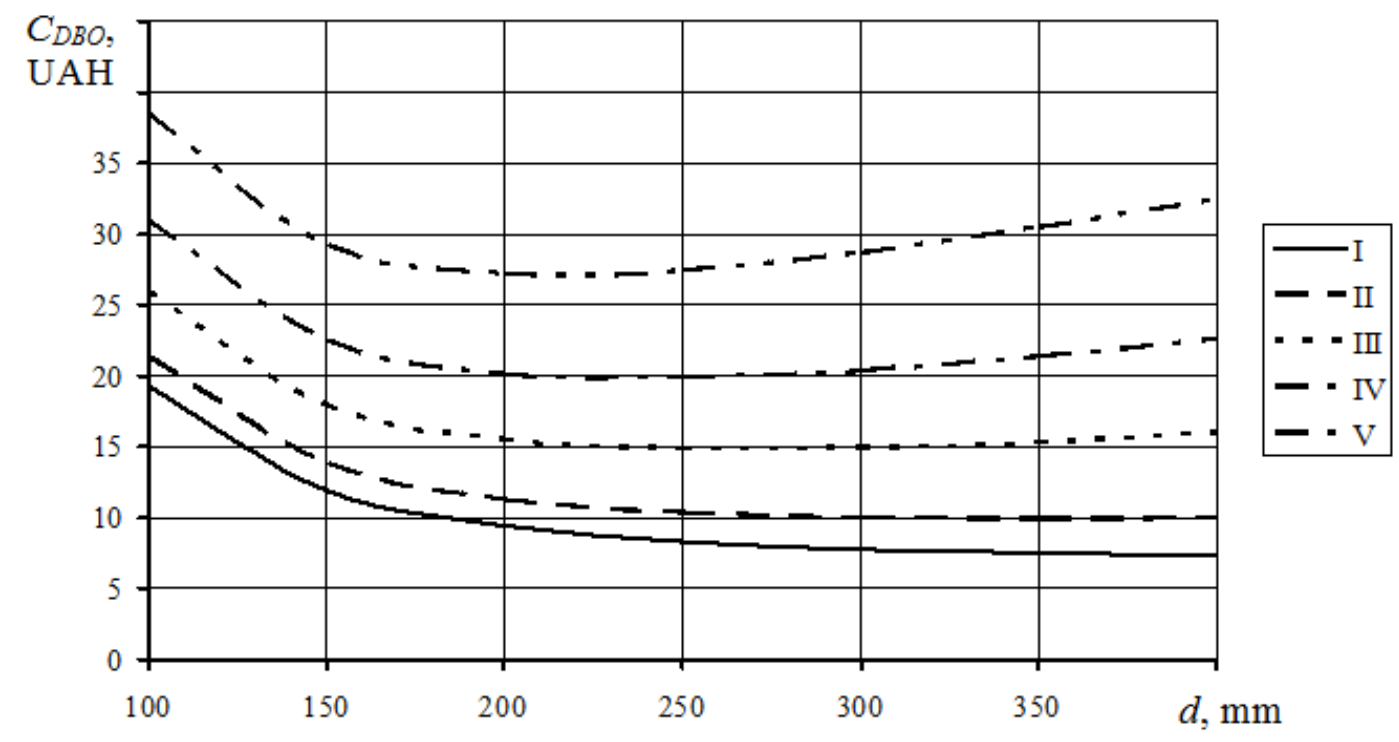

Figure 5 - T he dependence of the cost of drilling and blasting operations on the diameter of the well in the rocks of shale horizons for different categories of fracturing 


\section{ТЕОРЕТИЧНІ Й ЕКСПЕРИМЕНТАЛЬНІ ДОСЛІДЖЕННЯ \\ ПРОЦЕСІВ РУЙНУВАННЯ ГІРСЬКИХ ПОРІД ВИБУХОМ}

Thus, if we summarize the data analysis from Fig. 1-5 when drilling wells with SBSh-250 type machines, it can be seen that for category I of fracturing of massifs for the vast majority of rocks the charge diameter $d=400 \mathrm{~mm}$ will be most appropriate. For the second category $-d=350 \mathrm{~mm}$, for the III category of fracture $-d=250 \mathrm{~mm}$, for IV category of fracture the diameter is $d=250 \mathrm{~mm}$, V category of fracture (lowblock almost monolithic) $-d=200 \mathrm{~mm}$.

CONCLUSIONS. According to the results of the research performed, it was established that the diameter of the borehole charge is one of the most important parameters for controlling the degree of fragmentation, and its choice depends on the strength and fracture of the rocks.

An improved method for determining the rational diameter of wells for drilling and blasting in quarries has been proposed. An expression is obtained that relates the cost indicators of drilling and blasting to the main technological indicators of drilling and blasting operations, including the diameter of the wellhead explosive charge.

For the mining and geological conditions of the Krivbass iron ore quarry, calculations were carried out to establish the relationship between the diameter of the downhole explosive charge and the cost of drilling and blasting for various rocks with varying degrees of fracturing.

It was established that when drilling works are performed by SBSH machines, for category I fracture for all rocks of the deposit, the charge diameter $\mathrm{d}=400 \mathrm{~mm}$ is rational, for the second category $-d=350 \mathrm{~mm}$, for category III $-d=250 \mathrm{~mm}$, for category IV $-d=250 \mathrm{~mm}$; V categories $-d=200 \mathrm{~mm}$.

\section{REFERENCES}

1. Tishchenko, S. V., Eremenko, G. I., Fedin, K. A. (2012), "Features of the mechanism of destruction of rocks by differentiated borehole charges of explosives", Visnyk Kryvoriz'kogo nacional'nogo universytetu, no. 32, pp. 25-28.

2. Frolov, O., Kosenko, T., Maltseva, Yu. (2018) "Establishment of effective technological parameters at the contour blasting of borehole charges", Suchasny resursoenergozberigauchi tehnolohii hirnychoho vyrobnytstva. Kremenchuk Mikhailo Ostrohradskyi National University, vol. 1, no. 21, pp. 29-37.

3. Shapurin, O. V., Sinichich, P. M. (2015) "Optimization of combined well drilling with formation of large diameter basins", Visnyk Kryvoriz'kogo nacional'nogo universytetu, no. 39, pp. 107-113.

4. Efremov, E. I., Nikiforova, V. A., Chebenko, Yu. N. (2012) "Influence of the blasthole diameter on explosive area contact with blasting breakage rock and output of fines fractions", Suchasny resursoenergozberigauchi tehnolohii hirnychoho vyrobnytstva. Kremenchuk Mikhailo Ostrohradskyi National University, vol. 2, no. 10, pp. 9-15.

5. Doludarev, V. N., Dzekun, Yu. V., Yurko, A. A., Golovina N. P. (2017) "Research of the effect of the charge design with inert and gas-forming additives on explosive crushing rocks", Suchasny resursoenergozberigauchi tehnolohii hirnychoho vyrobnytstva. Kremenchuk Mikhailo Ostrohradskyi National University, vol. 2, no. 20, pp. 26-32.

Сучасні ресурсоенергозберігаючі технології гірничого виробництва. Випуск 1/2019(23). 


\section{ТЕОРЕТИЧНІ Й ЕКСПЕРИМЕНТАЛЬНІ ДОСЛІДЖЕННЯ ПРОЦЕСІВ РУЙНУВАННЯ ГІРСЬКИХ ПОРІД ВИБУХОМ}

6. Frolov, A. A., Maltseva, Yu. S. (2017) "Problems of choosing the rational diameter of well charges in open pits", Materialy 7-i Mezhdunarodnoi nauchnoprakticheskoi konferentsii molodykh uchenykh i studentov «Opyt proshlogo - vzglyad v budushchee», Tula, TSU, pp. 30-35.

7. Shapurin, A. V., Levutsky, A. S., Dark, V. P. (2010) "On the effect of charge diameter on the efficiency of open pit mining", Razrabotka rudnykh mestorozhdenii, no. 93, pp. 23-27.

8. Metz, S. Yu., Antonov, A. Yu. (2014) "Effective complex of drilling and blasting operations during the development of ledges of increased height", Girnychyj visnyk, no. 97, pp. 7-11.

9. Shapurin, O. V., Serebrenikov, V. M., Shvov, Ye. M. (2012) "Investigation of interconnections between the properties of rocks, their energy absorption in the case of blasting and cultivating in a collapse", Visnyk Kryvoriz'kogo nacional'nogo universytetu, no. 30, pp. 18-23.

10. Kutuzov, B. N., Varenichev, A. A. (1976) "The choice of the rational diameter of explosive wells in open pits", Gornyi zhurnal [Mining Journal], no. 8, pp. 47-51.

11. Frolov, O. O., Maltseva, Yu. S. (2018) "Of certain effective borehole charge diameter taking into account the technical and economic assessment of drilling and blasting operations", Visnyk Kryvoriz'kogo nacional'nogo universytetu, no. 46, pp. 914.

\section{СОВЕРШЕНСТВОВАНИЕ МЕТОДИКИ ОПРЕДЕЛЕНИЯ РАЦИОНАЛЬНОГО ДИАМЕТРА СКВАЖИН ДЛЯ БУРОВЗРЫВНЫХ РАБОТ}

\section{А. А. Фролов, И. Д. Литвинчук}

НТУУ «Киевский политехнический институт имени Игоря Сикорского»

ул. Борщаговская, 115, г. Киев, 03056, Украина. E-mail: frolov @ geobud.kiev.ua

По результатам выполненных исследований установлено, что диаметр скважинного заряда является одним из наиболее важных параметров регулирования степени дробления, а его выбор зависит от прочности и трещиноватости пород. Предложена усовершенствованная методика определения рационального диаметра скважин для буровзрывных работ на карьерах. Получено выражение, связывающее стоимостные показатели бурения и взрывания с основными технологическими показателями буровзрывных работ, в том числе с диаметром скважинного заряда. Для горно-геологических условий карьера построены зависимости между диаметром скважинного заряда взрывчатого вещества и стоимостью буровзрывных работ для различных горных пород с разной степенью трещиноватости. Установлены рациональные диаметры скважинного заряда при выполнении буровых работ станками СБШ-250 для пород различной категории трещиноватости.

Ключевые слова: взрыв, диаметр, скважина, заряд, порода, карьер.

Стаття надійшла 29.04.2019.

Сучасні ресурсоенергозберігаючі технології гірничого виробництва. Випуск 1/2019(23). 